\title{
Peningkatan Kualitas dan Kemasan pada Kelompok Usaha Kerupuk Ikan di Desa Bendar Kecamatan Juwana Kabupaten Pati
}

\author{
Dina Prasetyowati ${ }^{1}$, Rasiman Rasiman ${ }^{2}$, Ipah Budi Minarti ${ }^{3}$, David Firna Setiawan ${ }^{4}$ \\ ${ }^{1}$ Prodi Pendidikan Matematika, Universitas PGRI Semarang \\ ${ }^{2}$ Prodi Pendidikan Matematika, Universitas PGRI Semarang \\ ${ }^{3}$ Prodi Pendidikan Biologi, Universitas PGRI Semarang \\ ${ }^{4}$ Prodi Pendidikan Ekonomi, Universitas PGRI Semarang
}

E-mail: dinaprasetyowati@gmail.com, mpdrasiman@yahoo.co.id, ipeh_mi2n@yahoo.co.id, davidfirnasetiawan@gmail.com

\begin{abstract}
Abstrak
Desa Bendar dikenal sebagai desa Nelayan karena mayoritas penduduk Desa Bendar adalah nelayan dengan jumlah sebesar 55,7\% atau 880 orang. Root of problem yang dihadapi oleh Desa Bendar, Kecamatan Juwana, Kabupaten Pati adalah banyaknya hasil tangkapan ikan para nelayan serta sumber daya manusia yang belum terberdayakan secara maksimal, sehingga belum dapat meningkatkan kesejahteraan masyarakat baik secara kelompok maupun individu di Desa Bendar. Mitra dalam pengabdian ini adalah Kelompok Usaha Bersama (KUB) Mina Melati. Dalam menjalankan usahanya, KUB Kerupuk Ikan Mina Melati masih menerapkan manajemen tradisional. Rendahnya pengetahuan anggota KUB Kerupuk Ikan Mina Melati menjadi salah satu penyebabnya terutama dalam hâl proses produksi dan pengolahan kerupuk yang baik dan manajemen pengelolaan usaha. Kegiatan yang dilaksanakan pengabdian ini adalah Seminar Tata Cara Mendapatkan PIRT dan Sertifikasi Layak Higienis, Uji Lab Kandungan Bahan Makanan Kerupuk, Perijinan PIRT untuk KUB Kerupuk Ikan Mina Melati, Pelatihan Desain Label Kemasan Kerupuk, Pelatihan Packaging. Dengan adanya program pengabdian ini diharapkan KUB Mina Melati dapat menghasilkan produksi kerupuk ikan yang higienis dan memiliki nilai jual yang tinggi. Apabila nilai jual dari hasil pengolahan kerupuk ikan tinggi, maka penghasilan warga akan meningkat, dan selanjutnya memberi dampak kepada peningkatan kesejahteraan masyarakat Desa Bendar dan menjadikan Desa Bendar sebagai Desa Sentra Kerupuk Ikan.

Kata kunci: Desa Nelayan, Kerupuk Ikan, Kesejahteraan

\section{Abstract}

Bendar Village is known as a Fisherman Village because the majority of the population of Bendar Village are fishermen with a total of $55.7 \%$ or 880 people. The root of the problem faced by Bendar Village, Juwana District, Pati Regency is the large number of fish catches by fishermen and human resources that have not been maximally empowered, so that they have not been able to improve the welfare of the community both as groups and individually in Bendar Village. Partners in this service are Mina Melati's Joint Business Group (KUB). In running its business, KUB Kerupuk Ikan Mina Melati still applies traditional management. The lack of knowledge of the members of the Mina Melati Fish Crackers KUB is one of the reasons, especially in terms of good cracker production and processing and business management. The activities carried out by this service were Seminar on Procedures for Obtaining PIRT and Proper Hygiene Certification, Lab Testing of Cracker Food Content, PIRT Licensing for Mina Melati Fish Crack KUB, Cracker Packaging Label Design Training, Packaging Training. With this service program, it is hoped that KUB Mina Melati can produce fish crackers that are hygienic and have a high selling value. If the selling value of the results of fish cracker processing is high, the income of the residents will increase, and in turn will have an impact on improving the welfare of the Bendar Village community and making Bendar Village a Fish Crackers Center.
\end{abstract}

Key Word: Fishing Village, Fish Crackers, Welfare

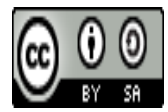




\section{Pendahuluan}

Desa Bendar merupakan desa yang terletak di pinggir Sungai Juwana, berjarak sekitar $14 \mathrm{~km}$ arah timur Kabupaten Pati atau sekitar 2,5 km arah timur Kecamatan Juwana. Secara administratif desa ini berada dalam Kecamatan Juwana, Kabupaten Pati, Provinsi Jawa Tengah. Desa Bendar mempunyai luas 198,197 ha atau sekitar 3,54\% dari keseluruhan luas Kecamatan Juwana seluas 5.592,598 ha. Desa Bendar terletak di daerah pantai, dengan ketinggian tanah dari permukaan laut 5,80 meter, banyaknya curah hujan $36,80 \mathrm{~mm}$ per tahun dan suhu udara rata-rata $34^{\circ} \mathrm{c}$. Sedangkan batas-batas wilayahnya adalah sebelah utara dengan Desa Growong Lor, sebelah selatan dengan Desa Bumirejo, sebelah barat dengan Sungai Silugonggo dan Desa Bajomulya, serta sebelah timur dengan Desa Trimulyo. Jarak desa ini dari Kecamatan Juwana adalah 2 km, dengan Kabupaten Pati 14 km, dengan Propinsi Jawa Tengah $91 \mathrm{~km}$, dan jarak dengan Ibukota Negara $661 \mathrm{~km}$ (Monografi Desa Bendar, 2018). Mata pencaharian mayoritas penduduk Desa Bendar adalah nelayan dengan jumlah sebesar 55,7\% atau 880 orang. Karena itulah desa Bendar dikenal sebagai desa Nelayan.

Berdasarkan hasil wawancara dengan Bapak Supeno, salah satu nelayan dan pemilik kapal di Bendar mengatakan bahwa sekali melaut hasil maksimal ikan yang diperoleh 300 ton untuk melaut selama 1 bulan dengan membawa 20 anak buah kapal. Ikan tangkapannya berupa ikan tongkol, kapasan, muniran, tunul, abangan, rajungan, telo dan pari. Dalam setahun, nelayan bisa 7 sampai 8 kali melaut. Itu hasil dari satu kapal, sedangkan penduduk Bendar banyak yang mempunyai kapal. Potensi ikan yang cukup besar perlu dikelola untuk dapat menghasilkan produk olahan yang memiliki nilai ekonomi tinggi. Salah satu bentuk adalah inovasi membuat makanan olahan ikan baik berupa kerupuk maupun terasi yang merupakan diverfisikasi produk ikan.

Potensi hasil tangkapan ikan para nelayan yang cukup besar di Desa Bendar, oleh masyarakat setempat telah diolah menjadi produk kerupuk ikan. Produksi pengolah kerupuk ini dilakukan oleh masyarakat dalam bentuk industri rumahan. Berdasarkan skalanya, usaha ini termasuk industri rumah tangga. Namun demikian melihat omset usaha maupun peluang pasarnya, usaha kerupuk ikan ini mempunyai rantai panjang dan melibatkan banyak tenaga kerja, sehingga sangat berpengaruh terhadap aktivitas perekonomian masyarakat.

Mitra dalam pengabdian ini adalah KUB Mina Melati. Dalam menjalankan usahanya, KUB Kerupuk Ikan Mina Melati masih menerapkan manajemen tradisional. Rendahnya pengetahuan anggota KUB Kerupuk Ikan Mina Melati menjadi salah satu penyebabnya terutama dalam hal proses produksi dan pengolahan kerupuk yang baik dan manajemen pengelolaan usaha. Berdasarkan survei dan wawancara langsung terhadap anggota mitra, permasalahan yang dihadapi mitra yang tergabung dalam KUB Mina Melati salah satunya adalah aspek kualitas dan kemasan.

Dari segi kualitas penampilan masih banyak kerupuk yang memiliki bentuk dan ketebalan yang tidak sama. Hal ini dikarenakan alat pemotong yang digunakan masih sederhana. Sementara untuk packaging atau pengemasan yang selama ini sebagian besar para pengusaha kerupuk di Desa Bendar belum menerapkan alat vacum dalam pengemasan. Kemasan yang digunakan hanya plastik kiloan sehingga tidak menarik pembeli. Kualitas kadar gizi dan komposisi dari kerupuk ikan juga tidak dicantumkan dalam kemasan. Selain itu produksi kerupuk ikan ini belum mendapatkan PIRT.

Tujuan dari kegiatan pengabdian ini adalah (1) Memberikan solusi permasalahan masyarakat Desa Bendar dengan pendekatan holistik riset multi disiplin, (2) Memberikan penguatan potensi masyarakat Desa Bendar melalui aplikasi hasil riset berupa pembuatan kerupuk ikan, (3) Meningkatnya pendapatan masyarakat Desa Bendar untuk kesejaterahan hidupnya, (4) Membentuk desa mitra sebagai Desa Sentra Kerupuk Ikan sebagai salah satu model science-techno-park Universitas PGRI Semarang, (5) Membantu program pemerintah Kabupaten Pati dalam pembangunan masyarakat dan wilayah di Desa Bendar.

Dengan adanya program pengabdian ini diharapkan masyarakat Desa Bendar dapat menghasilkan produksi kerupuk ikan yang memiliki nilai jual yang tinggi. Apabila nilai jual dari hasil pengolahan kerupuk ikan tinggi, maka penghasilan warga akan meningkat, dan selanjutnya memberi dampak kepada peningkatan kesejahteraan masyarakat Desa Bendar. Selain itu tujuan kegiatan ini juga terbentuknya desa Bendar sebagai Desa Sentra Kerupuk Ikan. 
Sasaran Kegiatan ini adalah Desa Bendar, Kecamatan Juwana, Kabupaten Pati. Khususnya bagi Kelompok Usaha Bersama (KUB) Kerupuk Ikan Mina Melati. Root of problem yang dihadapi oleh Desa Bendar, Kecamatan Juwana, Kabupaten Pati adalah banyaknya hasil tangkapan ikan para nelayan serta sumber daya manusia yang belum terberdayakan secara maksimal, sehingga belum dapat meningkatkan kesejahteraan masyarakat baik secara kelompok maupun individu di Desa Bendar. Urgensi permasalahan prioritas untuk menjadikan Desa Bendar sebagai sentra desa kerupuk ikan yaitu Aspek Kualitas dan Packaging. Dari urgensi permasalahan tersebut, maka tim pengusul dari Universitas PGRI Semarang menawarkan solusi dari permasalahan yang memang ingin dipecahkan dalam pengabdian ini. Solusi permasalahan ini merupakan hasil kesepakatan antara tim pengusul dari Universitas PGRI Semarang dengan kelompok mitra yaitu Kelompok Usaha Bersama (KUB) Kerupuk Ikan "Mina Melati”.

Solusi yang ditawarkan berupa berupa pelatihan-pelatihan, pembinaan, pendampingan, dan pemberian ketrampilan kepada penduduk desa Bendar untuk mengelola potensi hasil ikan yang dimiliki, sehingga hasilnya benar-benar dapat meningkatkan kesejahteraan masyarakat di sekitarnya. Solusi yang ditawarkan pada aspek kualitas dan packaging ini adalah Seminar Tata Cara Mendapatkan PIRT dan Sertifikasi Layak Higienis, Uji Lab Kandungan Bahan Makanan Kerupuk, Perijinan PIRT untuk KUB Kerupuk Ikan Mina Melati, Pelatihan packaging dan desain kemasan sehingga produk kerupuk ikan yang dihasilkan nantinya mempunyai daya tahan (tingkat keawetan) yang lebih lama dan penampilan yang lebih menarik.

\section{Metode Pelaksanaan}

Metode pelaksanaan program pengabdian ini berupa pelatihan-pelatihan, pembinaan, pendampingan, dan pemberian ketrampilan kepada penduduk desa Bendar untuk mengelola potensi hasil ikan yang dimiliki, sehingga hasilnya benar-benar dapat meningkatkan kesejahteraan masyarakat di sekitarnya. Metode pelaksanaan ini merupakan hasil kesepakatan antara tim pengusul dari Universitas PGRI Semarang dengan mitra Kelompok Usaha Bersama (KUB) Kerupuk Ikan Mina Melati.

Solusi yang ditawarkan pada aspek produksi adalah (1) Seminar Tata Cara Mendapatkan PIRT dan Sertifikasi Layak Higienis, (2) Uji Lab Kandungan Bahan Makanan Kerupuk, (3) Perijinan PIRT untuk KUB Kerupuk Ikan Mina Melati, (4) Pelatihan Desain Label Kemasan Kerupuk, (5) Pelatihan Packaging. Solusi yang ditawarkan oleh Universitas PGRI Semarang diharapkan menghasilkan produksi kerupuk ikan yang memiliki nilai jual yang tinggi. Apabila nilai jual dari hasil pengolahan kerupuk ikan tinggi, maka penghasilan warga akan meningkat, dan selanjutnya memberi dampak kepada peningkatan kesejahteraan masyarakat Desa Bendar.

Dalam setiap kegiatan baik dalam penanganan aspek kualitas dan kemasan, perlu melibatkan peran serta mitra. Keterlibatan mitra bukan hanya pada aspek pelaksanaan, tetapi mulai dari komunikasi masalah, perencanaan program, serta pelaksanaan, sehingga ketercapaian target luaran dan kesinambungan program lebih terjamin. Partisipasi mitra diantaranya adalah (1) menyediakan tempat untuk pelaksanaan kegiatan pelatihan, (2) kesediaan mitra untuk mengikuti kegiatan pelatihan yang diprogramkan dengan sebaik baiknya, (3) kesediaan mitra untuk mensosialisasikan atau menularkan pengetahuan dan keterampilan yang didapat kepada warga yang lain.

Target luaran dalam pengabdian ini adalah (a) meningkatnya mutu kualitas kerupuk ikan dan variasi olahan ikan, (b) mendapatkan ijinPIRT, (c) kualitas kemasan kerupuk ikan lebih menarik, (d) kualitas packaging lebih baik. Pada akhir program, tim pengusul akan melaksanakan evaluasi sebagai umpan balik dari pelaksanaan program. Evaluasi dilakukan untuk mengetahui apakah pelatihanpelatihan, pembinaan, pendampingan, dan pemberian ketrampilan yang sudah dilakukan dapat memberikan kontribusi pada mitra untuk menyelesaikan masalah yang dihadapi mitra pada program pengabdian ini. Tidak hanya itu, pelatihan juga perlu dievaluasi untuk memutuskan apakah program pelatihan tersebut perlu dilanjutkan atau tidak, yang terakhir adalah evaluasi program dilakukan untuk mendapatkan informasi mengenai bagaimana meningkatkan dan mengembangkan program pelatihan yang akan datang. 

ini.

Desain tahapan yang digunakan dalam program pengabdian dapat dilihat dalam bagan dibawah

Tahap Persiapan

- Survey Lokasi

- Inisiatif Gagasan

- Wawancara dengan masyarakat Desa

Bendar

Tahap Pembinaan dan Pelatihan

Aspek Kualitas dan Packaging

1. Seminar Tata Cara Mendapatkan PIRT dan Sertifikasi Layak Higienis

2. Uji Lab Kandungan Bahan Makanan Kerupuk

3. Perijinan PIRT untuk KUB Kerupuk Ikan Mina Melati

4. Pelatihan Desain Label Kemasan Kerupuk

5. Pelatihan Packaging

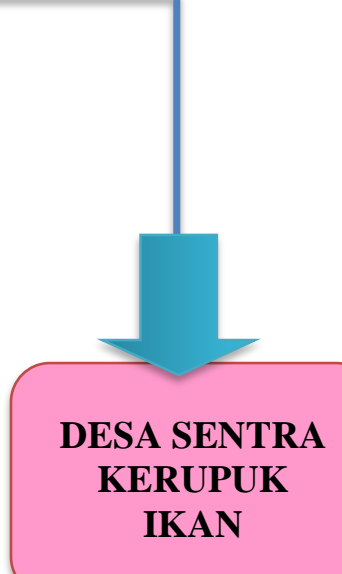

Aplikasi hasil riset Universitas PGRI Semarang tentang penerapan sains, teknologi unggulan dan pemberdayaan masyarakat

\section{Tahap Pendampingan dan evaluasi dalam pembentukan usaha bersama}

\section{Gambar 1. Desain Tahapan Prosedur dan Metode Pelaksanaan Pengabdian}

\section{Hasil Dan Pembahasan}

Menyadari nilai strategis dari kemajuan desa Bendar, baik menurut aspek ekonomi, teknologi, dan ketahanan pangan serta melihat banyaknya potensi hasil tangkapan ikan nelayan di Desa Bendar yang belum dioptimalkan pengolahannya itu, maka LPPM Universitas PGRI Semarang melalui tim pengabdian berkewajiban untuk membantu mengatasi masalah yang dihadapi masyarakat melalui penerapan sains dan teknologi unggulan untuk menjadikan Desa Bendar sebagai Sentra Desa Kerupuk Ikan. Pelaksanaan pengabdian ini difokuskan pada aspek kualitas dan kemasan. Hasil pelaksanaan program kerja yang telah dilaksanakan dalam pengabdian ini adalah sebagai berikut. 


\subsection{Seminar Tata Cara Mendapatkan PIRT dan Sertifikasi Layak Higienis}

Seminar tata cara mendapatkan PIRT dan sertifikasi layak higienis dilaksanakan pada hari Rabu, 6 Mei 2020 secara online yang diadakan oleh Lembaga Pemberdayaan Ekonomi Mustahik (LPEM) BAZNAS dalam kegiatan UMKM Class Online. KUB Mina Melati sebanyak 20 orang mengikuti kegiatan seminar ini. Kegiatan dilakukan dengan menyaksikan materi yang disampaikan melalui Laptop ataupun HP masing-masing peserta. Peserta yang mengikuti kegiatan ini mendapatkan sertifikat. Pemateri dalam UMKM Class Online kali ini disampaikan langsung oleh Dra. Dewi Prawitasari, Apt, M. Kes (Direktur Pemberdayaan Masyarakat dan Pelaku saha BPOM RI) dan moderator yakni Raden Ahmad Nabhan (Koordinator Pengembangan Usaha LPEM BAZNAS). Izin edar diberikan pada produk pangan yang telah memenuhi standar kemanan dan mutu. Keamanan pangan menjadi sesuatu hal yang sangat penting dewasa ini, mengingat banyaknya produk pangan yang beragam jenis yang diproduksi baik dalam dan luar negeri. Untuk itu pemerintah perlu membuat rantai pangan secara terpadu untuk melindungi masyarakat dari pangan yang tidak aman dan membahayakan kesehatan. Keuntungan dari izin edar suatu produk pangan selain dapat menjamin bahwa produk yang dihasilkan adalah bermutu baik dan aman juga dapat meningkatkan kepercayaan konsumen, sehingga pasarnya lebih luas dan omzet penjualanpun akan meningkat (BSN, 2017).

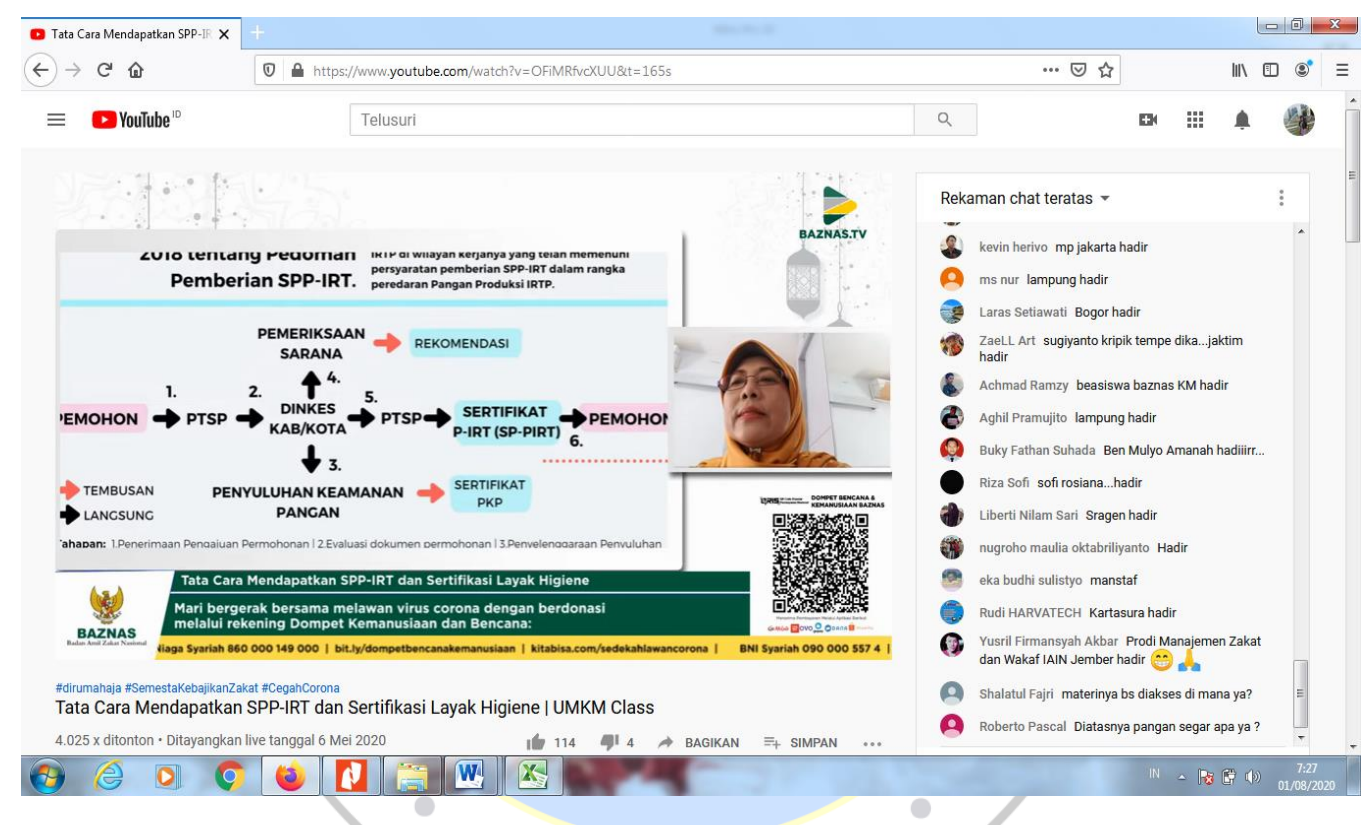

\section{Gambar 2. Seminar Tata Cara Mendapatkan PIRT dan Sertifikasi Layak Higienis}

\subsection{Uji Lab Kandungan Bahan Makanan Kerupuk}

Hasil produksi kerupuk yang dihasilkan oleh KUB Kerupuk Ikan Mina Melati diuji kandungan yang ada dalam kerupuk tersebut. Uji lab ini memberikan fungsi agar kerupuk yang diproduksi KUB Mina Melati aman untuk diperjual belikan dan di konsumsi oleh masyarakat luas, oleh karena itu perlu diadakan uji coba laboratorium sebagai salah satu bentuk tanggung jawab atas produk yang dihasilkan. Uji lab kandungan kerupuk ini dilakukan di Labortorium Teknologi Pangan Universitas PGRI Semarang. Uji lab yang dilakukan adalah kadar air, kadar abu, kadar protein, dan kadar lemak. Hasil dari uji lab ini akan digunakan sebagai salah satu persyaratan untuk mengurus perijinan Pangan Industri Rumah Tangga (PIRT). Berdasarkan hasil analisis kimia didapatkan kadar protein sebesar 24,38\%, kadar lemak sebesar 1,6\%, kadar pati sebesar 44,69\% dan kadar air sebesar 5,5\%. Dan dari parameter analisis fisik didapatkan volume pengembangan yaitu sebesar 146,43\% dan kadar kerenyahan yaitu sebesar $0,56 \mathrm{~mm} /$ detik/50gram. Proses pengeringan sangat berpengaruh terhadap kadar air pada kerupuk. Jika kandungan kadar air dalam kerupuk cukup tinggi maka akan lebih rentan akan tumbuhnya bakteri dan jamur. 
Hal ini sejalan dengan penelitian dari Mahfuz dkk (2017) bahwa kerupuk yang kering memiliki kadar air yang rendah $10 \%$ dari kadar air semula (sebelum pengeringan), tandanya adalah berbunyi bila dipatahkan dan hasil pengeringan disebut dengan kerupuk mentah.

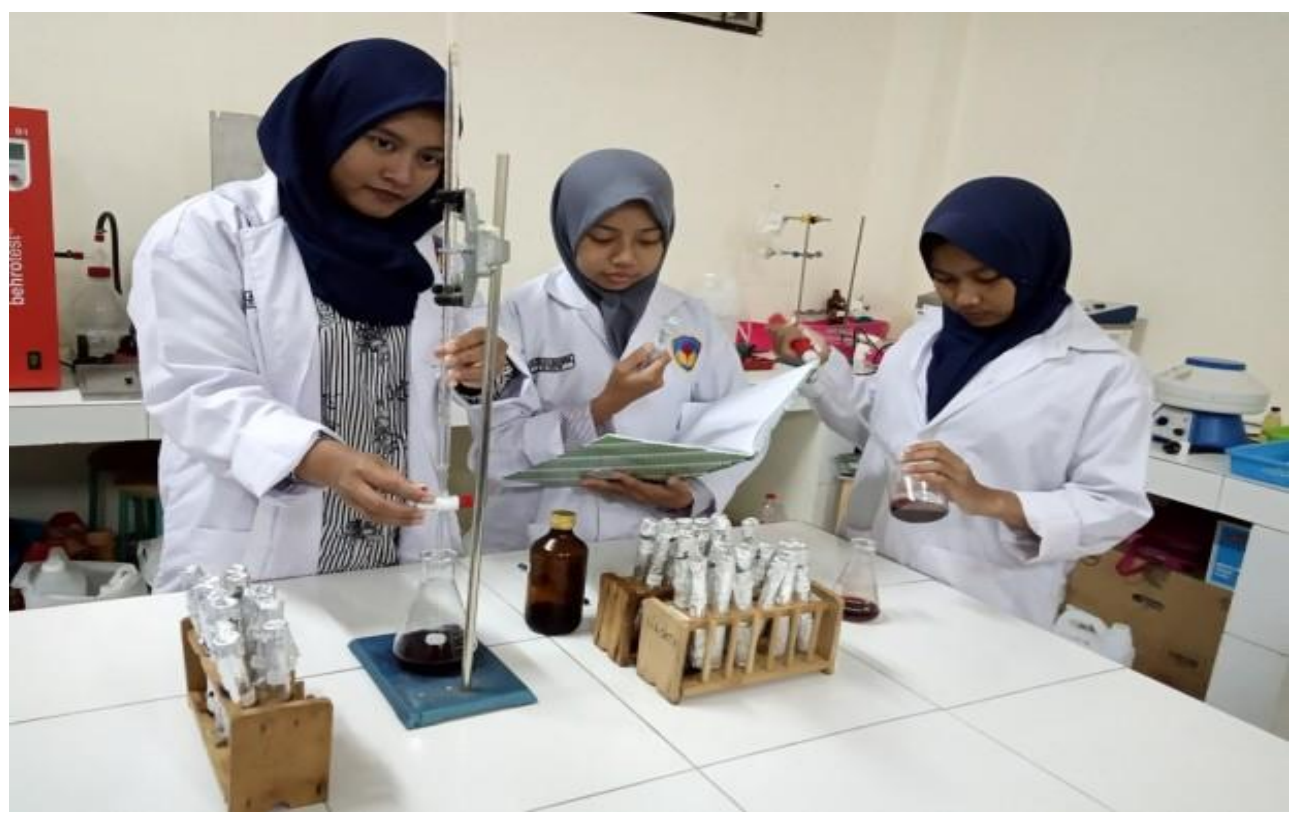

Gambar 3. Uji Lab Kandungan Bahan Makanan Kerupuk

\subsection{Perijinan PIRT untuk KUB Kerupuk Ikan Mina Melati}

Tim Pengabdi dari Universitas PGRI Semarang memberikan fasilitas pengurusan perijinan Pangan Industri Rumah Tangga (PIRT) untuk Kelompok Usaha Bersama (KUB) Kerupuk Ikan Mina Melati. Setiap produk pangan dari UKM memang sudah seharusnya mendapat sertifikat PIRT dari dinas kesehatan. Maka dari itu, sudah saatnya pa

ra pelaku UKM sadar terhadap pentingnya mendaftarkan produk pangan untuk mendapatkan izin PIRT supaya produk makanan atau minuman industri rumah tangga dapat bersaing dengan produk pabrikan. Tak terkecuali juga KUB Kerupuk Ikan Mina Melati.

Dokumen yang harus dipersiapkan dalam pengurusan sertifikat PIRT ini adalah sebagai berikut. (diambil dari laman simyandu.patikab.go.id)

1. Fotokopi kartu tanda penduduk (KTP) pemilik usaha rumahan

2. Pasfoto $3 \times 4$ pemilik usaha rumahan, 3 lembar

3. Surat keterangan domisili usaha dari kantor camat

4. Denah lokasi dan denah bangunan

5. Surat keterangan puskesmas atau dokter untuk pemeriksaan kesehatan dan sanitasi

6. Surat permohonan izin produksi makanan atau minuman kepada Dinas Kesehatan

7. Data produk makanan atau minuman yang diproduksi

8. Sampel hasil produksi makan atau minuman yang diproduksi

9. Label yang akan dipakai pada produk makanan minuman yang diproduksi

10. Menyertakan hasil uji laboratorium yang disarankan oleh Dinas Kesehatan

11. Mengikuti Penyuluhan Keamanan Pangan untuk mendapatkan SPP-IRT 


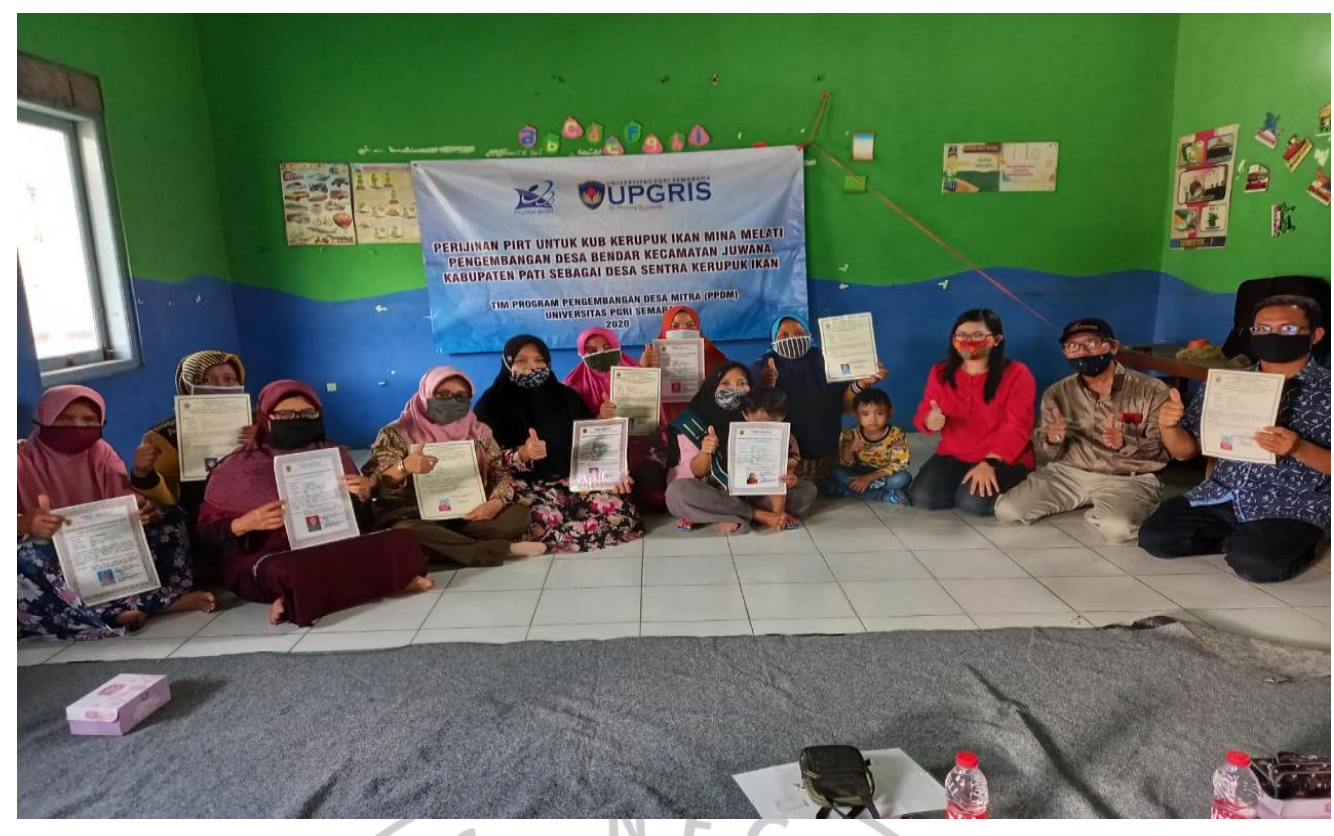

Gambar 4. Penyerahan Sertifikat PIRT untuk KUB Mina Melati
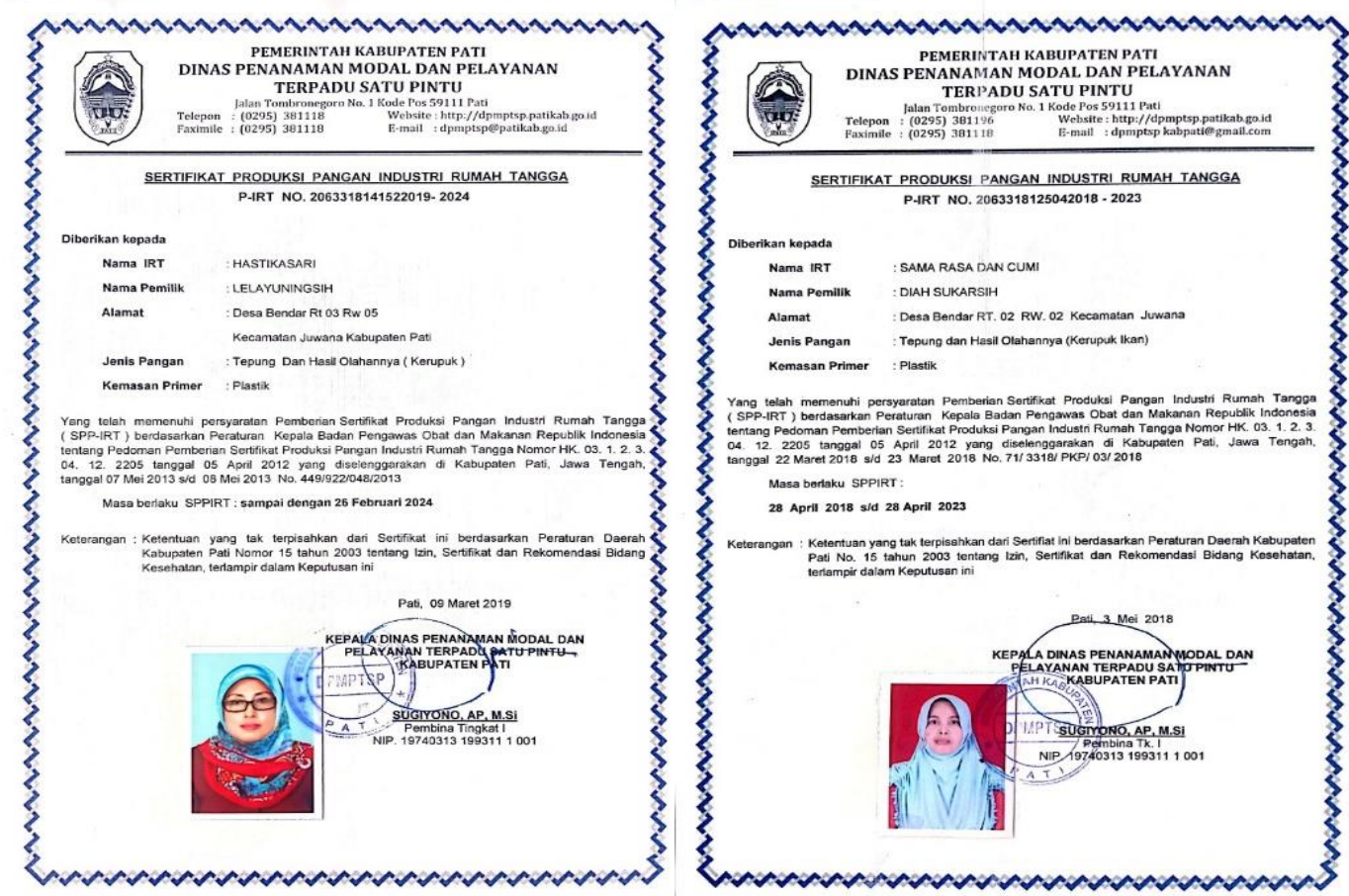

Gambar 5. Salah Satu Sertifikat PIRT yang diterima KUB Mina Melati

\subsection{Pelatihan Desain Label Kemasan Kerupuk}

Pelatihan ini dilaksanakan pada hari Minggu, 19 Juli 2020. Kegiatan ini diikuti oleh anggota KUB Kerupuk Ikan Mina Melati. Pemateri dalam kegiatan ini adalah Achmad Buchori. Dalam kegiatan ini, pemateri menyampaikan bahwa secara umum, ada 7 hal yang diperhatikan oleh konsumen saat mereka membaca label produk olahan pangan. Apabila kita memiliki produk makanan, pastikan tidak lupa mencantumkan Nama pangan olahan, Berat bersih, Nama dan alamat produsen atau distributor, 
Daftar bahan yang digunakan atau komposisi, Nomor pendaftaran pangan, Keterangan kadaluarsa dan Kode Produksi.

Selain itu, untuk melengkapi info tadi, kita juga perlu menambahkan data-data Keterangan kandungan gizi, Tulisan Halal, Keterangan petunjuk penyimpanan dan Peringatan Desain label kerupuk dari KUB Mina Melati masih sangat sederhana. Label dari kemasan tersebut juga terlihat tidak memenuhi syarat pembuatan label kemasan yang baik. Beberapa alasan dari kurang baiknya kemasan dan label yang dibuat KUB Mina Melati adalah ketakutan akan mahalnya biaya pembuatan kemasan serta masih kurang pahamnya KUB Mina Melati cara untuk mendapatkan kemasan yang menarik tetapi terjangkau harganya serta dimana mendapatkannya. Umumnya mereka tidak sadar atau kurang memahami bahwa desain kemasan yang baik dan menarik akan mendatangkan nilai lebih pada produk yang dijual. Rata rata desain kemasan yang digunakan pada KUB Mina Melati hanya satu warna. Contoh desain kemasan kerupuk KUB Mina Melati sebelumnya dapat dilihat pada gambar berikut.
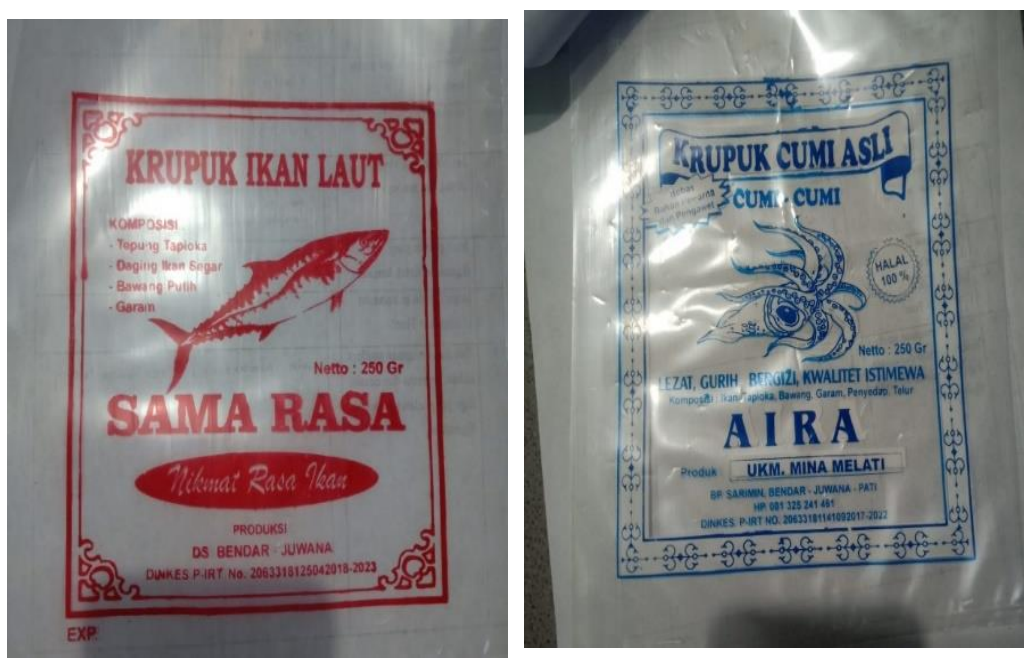

\section{Gambar 6. Desain Label Kemasan Kerupuk KUB Mina Melati Sebelumnya}

Contoh label kemasan Kerupuk KUB Mina Melati yang baru dapat dilihat pada gambar berikut.
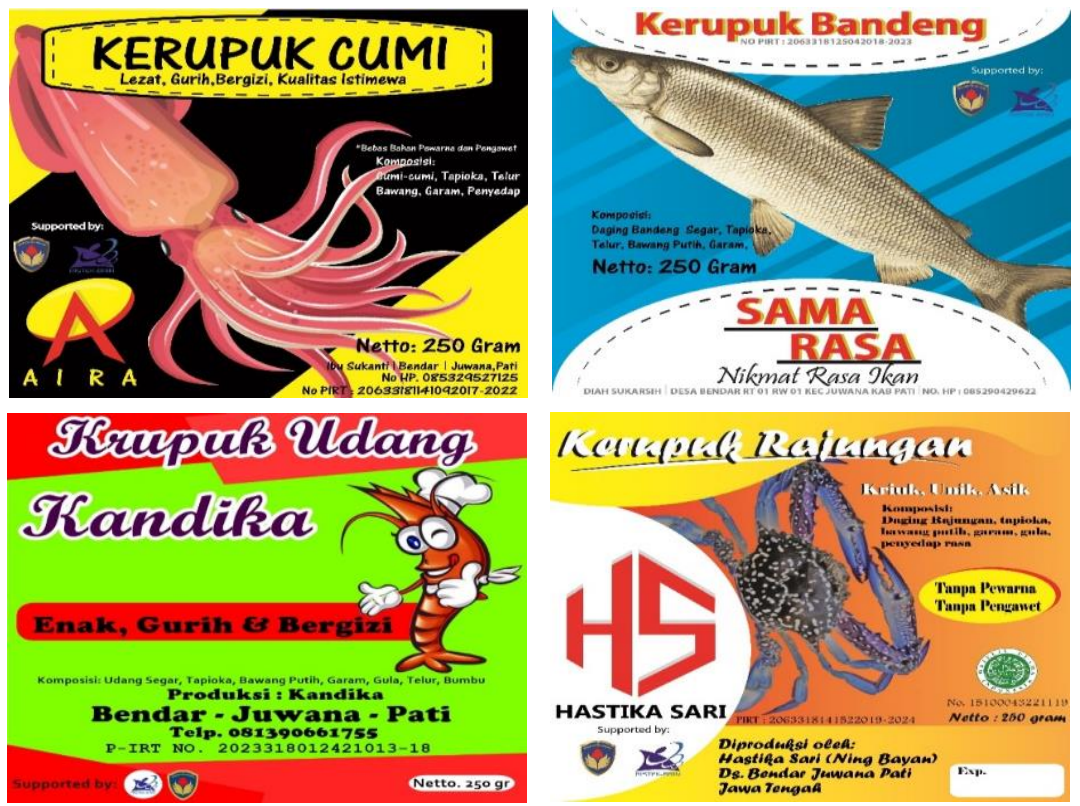

Gambar 7. Desain Label Kemasan Kerupuk KUB Mina Melati yang Baru 


\subsection{Pelatihan Packaging}

Pelatihan ini dilaksanakan pada hari Minggu, 30 Agustus 2020. Kegiatan ini diikuti oleh anggota KUB Kerupuk Ikan Mina Melati. Pemateri dalam kegiatan ini adalah David Firna Setiawan. Dalam kegiatan ini, pemateri menyampaikan bahwa packaging/kemasan merupakan proses yang berkaitan dengan perancangan dan pembuatan wadah atau pembungkus suatu produk. Fungsi dari kemasan, yaitu: 1) Pelindung isi, 2) Kemudahan menggunakan produk, 3) Pemakaian ulang, 4) Daya Tarik, 5) Identitas, 6) Distribusi, 7) Informasi, 8) Kemajuan teknologi dan daur ulang.

Kemasan produk merupakan salah satu unsur penting yang mempengaruhi banyaknya permintaan konsumen dan banyaknya penjualan terhadap produk. Wiguna (2007) dalam penelitiannya menemukan bahwa kemasan berpengaruh terhadap keputusan membeli pada produk jajan di Kota Gresik. Ini menunjukkan salah satu bukti bahwa kemasan merupakan hal penting yang dapat meningkatkan penjualan dan keberhasilan usaha. Kemasan yang digunakan KUB Mina Melati hanya plastik kiloan sehingga tidak menarik pembeli. Contoh kemasan kerupuk KUB Mina Melati sebelumnya dapat dilihat pada gambar berikut.

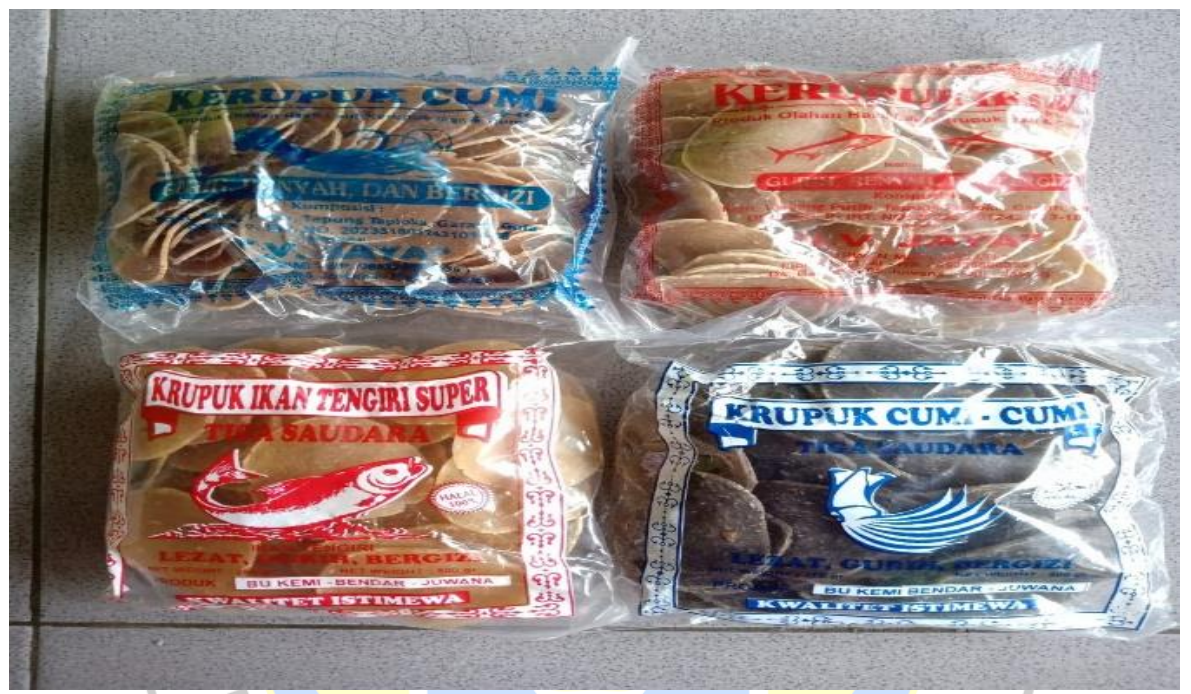

Gambar 8. Kemasan Kerupuk KUB Mina Melati Sebelumnya

Contoh label kemasan Kerupuk KUB Mina Melati yang baru dapat dilihat pada gambar berikut.

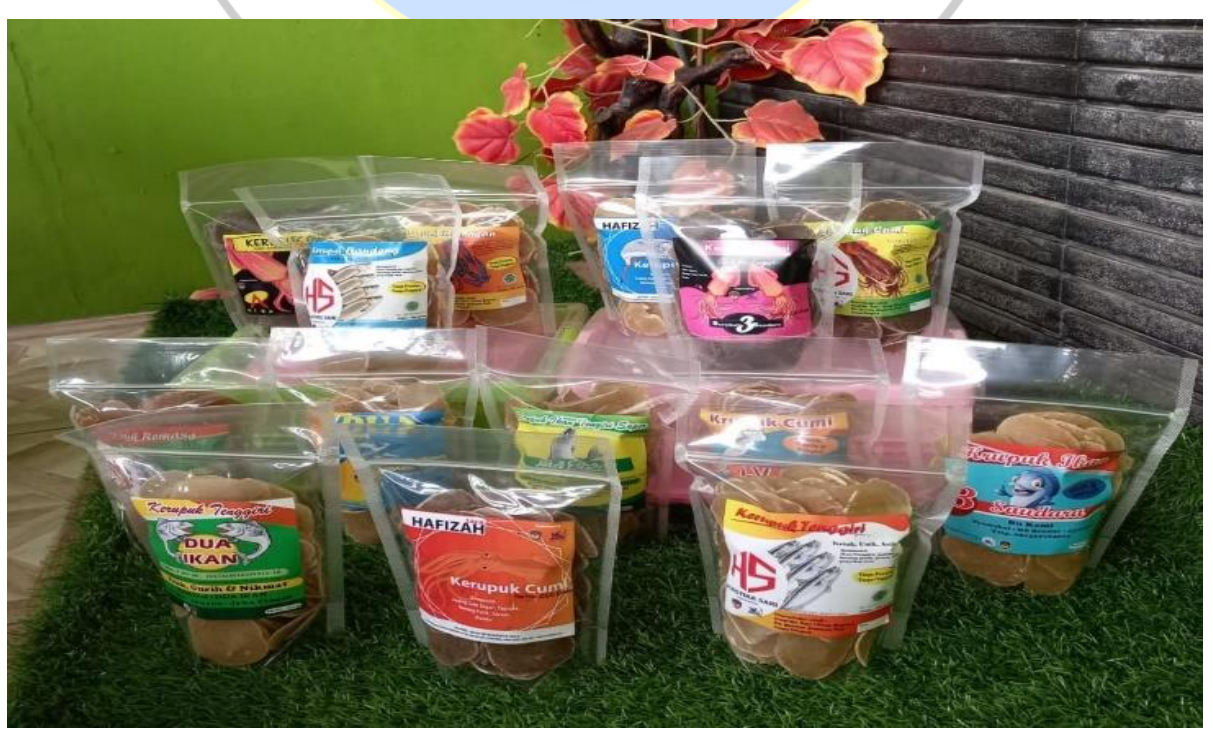

Gambar 7. Desain Label Kemasan Kerupuk KUB Mina Melati yang Baru 


\section{Kesmpulan}

Melalui kegiatan pengabdian ini telah banyak memberikan pengetahuan dan pengalaman bagi warga desa bendar khususnya untuk KUB Mina Melati untuk menuju desa sentra kerupuk ikan. Kegiatan yang sudah dilaksanakan pada program pengabdian ini adalah sebagai berikut.

a. Seminar Tata Cara Mendapatkan PIRT dan Sertifikasi Layak Higienis.

b. Uji Lab Kandungan Bahan Makanan Kerupuk.

c. Perijinan PIRT untuk KUB Kerupuk Ikan Mina Melati.

d. Pelatihan Desain Label Kemasan Kerupuk.

e. Pelatihan Packaging

KUB Mina Melati sangat respon dan mendukung seluruh kegiatan pengabdian ini terlihat dari antusiasme mitra dalam mengikuti pelatihan dan workshop. Seluruh kegiatan pelatihan dan workshop berjalan lancar dan sukses tanpa ada kendala yang berarti. Saran yang diajukan adalah (1) ada pelatihan yang beragam guna mendukung pelatihan yang sudah dilaksanakan; (2) ada pendampingan dan evaluasi kegiatan setelah kegiatan pelatihan selesai; (3) dukungan dari pemangku kebijakan dan Pemerintahan sangat diperlukan untuk mewujudkan desa Bendar sebagai desa Sentra Kerupuk Ikan.

\section{Daftar Pustaka}

BSN. (2017). Produk Pangan Wajib Tersertifikasi Mutu dan Aman. Diakses pada 27 Maret 2020 dari http://bsn.go.id/main/berita/berita det/7900/Rancangan-SNI--tentang--KlasifikasiSumberDaya-dan-Cadangan-Energi-Panas-Bumi-Indonesia\#.WhrOf_mWbIV

Izin Produksi Pangan Industri Rumah Tangga. (2019) Diakses pada 29 Maret 2020 dari https://simyandu.patikab.go.id/portal/index.php?mod=license\&sub=LicenseDetailPO\&act=vie w\&typ=html\&izin $=54$

Mahfuz, H., Herpandi, H., \& Baehaki, A. (2017). Analisis Kimia dan Sensoris Kerupuk Ikan yang Dikeringkan dengan_Pengering Efek Rumah Kaca (ERK). FishtecH - Jurnal Teknologi Hasil Perikanan, 6(1), 39-46.

Monografi Desa Bendar. (2018). Gambaran Umum Desa Bendar. Diakses pada 15 Januari 2019, dari http://bendar-juwana.desa.id/gambaran-umum-desa/

Wiguna, S.P. (2007). Pengaruh Kemasan Produk terhadap Keputusan Konsumen dalam Membeli Produk Jajan Khas Kota Gresik. Skripsi. UIN Malang. 